\title{
CARL F. H. HENRY'S REGENERATIONAL MODEL OF EVANGELISM AND SOCIAL CONCERN AND THE PROMISE OF AN EVANGELICAL CONSENSUS
}

\author{
JERRY M. IRELAND* \\ University of Valley Forge, Phoenixville
}

\begin{abstract}
Carl F. H. Henry has widely been acknowledged for his contributions to evangelical social concern. What has not been fully appreciated though is theological foundations that undergirded Henry's priority model as it relates to the relationship between the church social and evangelistic mandates. For Henry, the key to both was the doctrine of revelation, and this foundation enabled Henry to uniquely argue for both integration and prioritization. As such, Henry presents a challenge to many contemporary models of evangelism and social concern that set the two on an even plane by locating them within a kingdom rubric. Despite accusations that his theological method fosters information over transformation, Henry hold forth a revelation centered approach with Augustinian roots capable of guiding the contemporary church on the elusive issue of finding a biblical approach to its mission.
\end{abstract}

KEYWORDS: Evangelism, Social Concern, Kingdom of God, Doctrine of Revelation, Preaching, Evangelism, Carl Henry

The question of how evangelism and social concern relate to one another in the mission of the church has long occupied theologians, pastors, and missiologists. As Carl F. H. Henry once observed, 'Perhaps no problem has distressed the modern churches more than determining the legitimacy of claims made upon Christian loyalties by champions of personal evangelism on the one hand and by those who call the Church to social involvement on the other. These tensions now vex the Church as never before in recent history' (Henry 1972: 3). The evangelical divide over this issue, though not entirely recent, became especially sharpened by the divisions that emerged from the fundamentalist-modernist controversy that peaked in the early decades of the twentieth century. Fundamentalism responded to the human-centered social agenda of liberal theology by mostly withdrawing from cultural engagement and social action. Rather than developing a more biblically balanced response to social issues, fundamentalism instead tended to

* JERRY M. IRELAND (PhD 2014, Liberty University; MA Global University) teaches theology at University of Valley Forge, Phoenixville, PA, United States of America. 
truncate the gospel's temporal relevance in favor of an exclusive focus on eternal matters (Henry 2003: 6; Marsden 1987: 4).

From within fundamentalism though, there emerged in the latter half of the twentieth century, a theologian whom some have considered an evangelical prophet, calling the church back to a more balanced perspective (Neuhaus 1989: 30). His name was Carl Henry. In 1947, at the age of thirtyfive, he published his clarion call for reform, The Uneasy Conscience of Modern Fundamentalism. In doing so, he established himself as a key thinker in the emerging neo-evangelical movement.

Henry devoted much of his academic life to the pursuit of evangelical unity. This is one of the things Russell Moore has shown in his book The Kingdom of Christ: The New Evangelical Perspective (2004). Henry's advocacy, along with that of others, for an evangelical consensus on the Kingdom of God as inaugurated eschatology emerged in part from Henry's concern for a united evangelicalism. But in 2009, six years after Henry died, a panel discussion at the Evangelical Theological Society (ETS), consisting of Moore, Richard Mouw, Craig Mitchell, and Peter Heltzel, all reflecting on the life and legacy of Carl F. H. Henry, agreed that Henry probably died a disappointed man. The primary reason for Henry's disappointment, according to the panel, was the reality of a still divided evangelicalism (cf. Thornbury 2013: 203).

It is worth pointing out, before I go further, that I have my theological differences with Carl Henry. He was a Reformed Baptist and I am an Arminian Pentecostal. That said, I am deeply convinced that Henry ought to be heard again by a new generation of thinkers and practitioners searching for solid biblical footing. In particular, I am persuaded that Carl Henry's regenerational model of evangelism and social concern-the focus of this essay-holds forth great promise for an evangelical consensus on an important issue that continues to divide the body of Christ.

\section{The Relevance of Carl Henry}

Why should we care what Carl Henry says about this issue? The simple answer is that no person in recent history has devoted more of their scholarly reputation or been at the center of more evangelical conferences, quests, or committees promoting a biblical view of both evangelism and social concern than Henry. Not only because of his extremely important book, The Uneasy Conscience, but also because, in addition to that volume, he wrote or edited over forty other books, plus hundreds of scholarly articles published in academic journals and in Christianity Today (CT). Henry not only helped found CT, but Fuller Seminary as well, and played important roles in the 1966 World Congress on Evangelism in Berlin, Key '73, Ronald Sider's The Chicago Declaration (also in 1973), and the first Lausanne Congress on World 
Evangelization in 1974. Undergirding every one of these was an effort to, in part, promote a very specific form of evangelicalism that exhibited biblical fidelity and embodied a passion for precisely the sort of social action and cultural engagement that had been missing in fundamentalism. This absence of temporal and social relevance was, in fact, what Henry considered to be fundamentalism's fatal flaw (Ireland 2015: 45-59; Cerillo and Dempster 1991: 369).

\section{The Revolt Against Prioritism}

Prior to Lausanne I (1974), prioritism, or the declaration that evangelism is the church's primary task, remained the dominant view among evangelicals, even in the midst of neo-evangelical reforms. Yet, ambiguities arising from the first Lausanne Congress led to further consultations aimed at bringing some degree of clarity. In particular, holism advocates from the Global South challenged prioritism, claiming that this idea was rooted in western individualism and thereby a cultural corruption of the Good News (Kirk 1983: 31; Stott 1996: 24; cf. Tizon 2008: 40-43). In recent years, this has led to an increased tendency away from a priority position in general and toward seeing evangelism and social concern as equally important in the church's mission. This perspective is evident in references that define these two mandates as 'two wings of the same gospel bird' or 'two sides of the same coin' (Miles 1986: preface).

People on both sides of this debate fear that the opposing perspective would lead to an imbalance. Priorists fear that holism diminishes evangelistic efforts (Little 2005). Holists, on the other hand, suspect that prioritism diminishes the church's ability to speak to issues of present human suffering and causes the church to be seen as uncaring. Some also argue that where social concern is not present, true disciples have not been made (cf. Sider 2011: 61; Kirk 1983: 92). As it relates to evangelical differences on this issue, Scripture plays the key role and both sides make their case based on various biblical texts (cf. Hesselgrave 2005: 118-138; Kirk 1983: Little 2013). But given the differences between the two perspectives, both positions cannot be right.

As the debate drags on, it becomes increasingly apparent that an evangelical solution capable of overcoming this divide must exhibit a passion for both evangelism and social concern, and be grounded in solid biblical principles. As I will briefly demonstrate, Henry achieves this and more because he develops the theological foundations for both, in greater depth than most. Most importantly, he does this specifically by a thorough defense of the doctrine of revelation. This emphasis on the doctrine of revelation is, furthermore, missing in almost every other attempt to resolve this issue. For example, John Stott, in his exposition of the Lausanne Covenant says that 
evangelism and social concern 'are necessary expressions of our doctrines of God and man' (1996: 25). But as is almost always the case, there is no explicit mention of the doctrine of revelation; and yet for Henry, it is this doctrine above all others that proves the fundamental issue.

\section{Prioritism and Integration}

There are many lessons to be learned from a study of Henry's thoughts on evangelism and social concern. Perhaps one of most important relates to a common assumption regarding the issue of priorities. In the evangelismsocial concern debate, holism proponents have often argued that integration-the idea that evangelism and social concern are theologically and practically intertwined-can only be sustained within a holistic model. Or, put another way, holists claim that integration and prioritism are mutually exclusive. For example, David Bosch says:

The moment one regards mission as consisting of two separate components, one has, in principle, conceded that each has a life of its own. One is then by implication saying that it is possible to have evangelism without a social dimension and Christian social involvement without an evangelistic dimension. What is more, if one suggests that one component is primary and the other secondary, one implies that one is essential, the other optional (1991: 405).

When I first began studying Henry (and in fact, one of the reasons I started studying Henry in the first place), I believed that I could show that either he was inconsistent, or that his theological foundations did not support his conclusions. The reason I thought this was because I had bought into this very popular claim made by David Bosch and others, declaring that integration and prioritism are mutually exclusive.

One thing that becomes very clear in a study of Henry's thoughts on evangelism and social concern is that he not only seems to speak the language of both camps, but also challenges some of the basic assumptions of each side. For example, in The Uneasy Conscience, Henry says, 'the evangelical task primarily is the preaching of the gospel in the interest of individual regeneration' (2003: 88). This is pretty standard fare for a priority argument. Yet, in one of his other works, Henry says things that sound very much like the statements made by those on the holism side. In A Plea for Evangelical Demonstration, he writes, 'the church must in life and word be the global echo of the Risen Christ's invitation to turn from judgment to joy. This address to the world is not only in audible words, but also in compassionate demonstration of gospel truth' (Henry 1971: 88). These two statements show that Henry's position emphasizes the priority of evangelism and the necessity of social concern. We are then forced to ask, on what theological grounds does Henry defend his position, and how does it relate to the 
claim made by Bosch? We will return to these questions shortly. For now, though, it should be evident that articulating Henry's priority argument requires some very careful nuancing.

The particular eloquence of Henry's position is this: one need not deny the important biblical commands regarding social justice in order to arrive at prioritism, and the way one does this is by understanding the full weight of the doctrine of revelation within Christian theology. When this is done, it becomes clear that there is a direct correlation between the doctrine of revelation and the priority of proclamation. However, such a prioritist position by no means renders what the Bible says about social justice as irrelevant or unimportant. In fact, the opposite is true. A high view of the doctrine of revelation, especially concerning Scripture, also gives rise to a robust social concern because the moral imperatives for God's people are divinely revealed (Henry 1986: 15).

\section{Revelation and Regeneration: The Foundations of Henry's Approach}

For Henry, the whole issue of the evangelism and social concern debate is first and foremost a theological problem. In addition, theology itself is always driven by one's epistemology. Epistemological assumptions determine theological conclusions. Because of this, Henry believes the only way to remain true to the nature and content of revelation is for revelation to provide the basis for epistemology and thereby become the determining factor in theological formulation. Henry, therefore, articulates a revelational epistemology that builds on Augustine's logos doctrine wherein the eternally incarnate Word mediates truthful knowledge from God to man (Henry 1999: volume 3, 168; Nash 1982: 59-68).

As such, the logos doctrine underscores the personal nature of God's revelation. God does not simply infuse creation with information, but intends to use that information to reach humanity. Furthermore, Henry makes use, again following Augustine, of the imago Dei to establish that human creatures are endowed with a divinely ordained capacity to reason rightly. Not even the noetic effects of sin have rendered this capacity incompetent (Henry 1988: 121). Therefore, humanity is everywhere confronted with God's revelation in both nature and Scripture. At the heart of Henry's approach is the idea that God's own gracious self-revelation constitutes the central feature of the Judeo-Christian heritage, and that there exists a fundamental connection between the doctrine of revelation and church's proclamational task. Specifically, the doctrine of revelation necessitates prioritism and renders social concern as necessary. This is because Christianity is fundamentally a redemptive religion, and revelation is given particularly on that account. 


\section{Henry and His Critics}

A number of Henry's critics have claimed that his propositional approach to theological method fosters a divide between right beliefs and right practice. In fact, this has become a standing critique of conservative evangelicalism in general, but it is particularly directed toward those who believe that theology can best proceed when the teachings of Scripture are formulated as true or false propositions. This criticism comes especially from proponents of a post-conservative theological method. Specifically, post-conservatives accuse Henry and others of holding to an epistemology that fosters an unbiblical rationalism emphasizing 'information over transformation' (Olson 2007: chapter five).

The critique that post-conservatives make here is really directed at Henry's epistemology, which drives his approach to propositions and to Scripture as a whole. These critics, such as Roger Olson and Kevin Vanhoozer, uncritically lump Henry together with Hodge and Warfield and claim that Henry's passion for propositions is (1) based on Cartesian foundationalism, and (2) is a product of Scottish common sense realism, both of which are methodologically problematic (Vanhoozer 2005: 5; Olson 2007: chapter two). This then raises the important question of whether Henry's priority position, itself, is the product of an overly rationalistic epistemology.

Henry's chief concern was the doctrine of revelation and he believed this to be the most endangered doctrine in the twentieth century. In addition, he felt that the doctrine of the Bible was the control doctrine for every other doctrine. Upon closer inspection, one notices that Henry is not a foundationalist in the Cartesian sense, nor is his method at all based on Scottish common sense realism (like Hodge's and Warfield's had been). He does not reduce all the genres of Scripture to propositions as he is accused of doing. Henry's method is Augustinian, not Cartesian (Henry 1990: 40). As such, Henry's foundational belief is not reason itself, but revelation and the necessity of revelation for all human knowledge. Human capacity for true knowledge of God and the world is possible only because God wills it and provides for it: 'The Christian knows... that it is only by divine grace that he believingly participates in the epistemic and ontic realities affirmed by the Biblical heritage' (Henry 1990: 51).

That Henry has grounded his theology in an Augustinian foundation of faith seeking understanding is evident in his affirmation of both the priority of faith and of a correspondent theory of truth that depends on the reality of divine revelation (Henry 1990: 40; Brand 1999: 15; Trueman 2000: 52). This approach stands miles apart from Cartesian foundationalism and should, therefore, be a source of tremendous embarrassment to Henry's post-conservative critics because they are so far off base. 
No one who has taken the time to read Henry's God, Revelation, and Authority, volume 1 (1976) and volume 2 (1976), along with his Toward a Recovery of Christian Belief (1990), would ever come to these conclusions, for Henry directly refutes these very accusations. No wonder Gregory Thornbury asks, 'Are these people reading the same Carl F. H. Henry that I am?' (2013: 59).

The fundamental difference between Henry and his critics lies in the tendency to equate rationalism with rationality. Rationalism can be defined as the elevation of supposed innate rational capacities built on a belief in the mind's unaided ability to reason rightly. Henry, however, does not believe that for a minute. Instead, he proposes a view of rationality (not rationalism) that allows reason to function within the provisions of God. Specifically, human reason is a product of the imago Dei and the mediating Logos, both means by which God provides for the flow of knowledge from Himself to humanity. On this view, human beings cannot know anything apart from God's provision. Since the people of God are called upon over and over again to reason rightly regarding true and false doctrine, the content of Christian theology must therefore lend itself to systematic and propositional forms. This, however, does not mean that ethical demands do not follow, nor as Olson wrongly assumes, that Henry is more concerned with information over transformation.

Henry's Augustinian model of revelation grounds knowledge in God's own nature and purposes and rests on two fundamental axioms. God himself constitutes the ontological axiom, and divine revelation constitutes the epistemological axiom. Henry argues, 'On these basic axioms depend all the core beliefs of biblical theism, including diving creation, sin and the Fall, the promise and provision of redemption, the incarnation of God in Jesus of Nazareth, the regenerate church as a new society, and a comprehensive eschatology' (1990: 49).

The core feature, therefore, of the doctrine of revelation is that God makes knowledge possible and does so, foremost, that He would be known among the nations. But God desires not to be known remotely, but personally and redemptively. This fundamental necessity of revelation and its grounding in God's regenerational purposes for lost humanity requires not only spiritual but also moral obedience (Henry 1999: volume 1, 232). Humanity's responsibility and culpability in both areas find grounding in eternal truths published in God's gracious self-revelation. This constitutes the essential link between revelation and Henry's regeneration model. The transcendent and verbal nature of this revelation therefore casts its net over the whole of human existence, calling all to acknowledge the Lordship of Christ (Henry 1990: 54). 


\section{Henry's Argument for the Priority of Evangelism}

Henry frequently championed the priority of evangelism. Furthermore, he understands evangelism as primarily a verbal-proclamational task. For example, he says, 'The unmistakable priority of God's people, the church in the world, is to proclaim God's revealed Word' (Henry 1999: volume 2, 22; emphasis added). As such, evangelism constitutes the church's only unique role in the world. If the church fails to heed this mandate it becomes an affront to God (Henry 1999: volume 2, 22). This characterized the apostolic church and should characterize the modern one as well:

To recall men to their created dignity, to rescue them from sin's hell and death, to renew them in salvation's grace and power, to awaken their sense of eternal destiny, and to renew them in the image of God, the church gave herself in glad obedience to the Great Commission of her Risen Head, and regarding fulfillment of this evangelistic mandate as her number one task in the world (Henry 1971: 64-65).

What especially distinguishes Henry's prioritist perspective is that it flows primarily from his understanding of the doctrine of revelation and its essentially redemptive thrust. 'The human species', he says, 'is on the receiving end of a divine initiative' (Henry 1999: volume 2, 30; cf. Thornbury 2013: $64)$. In other words, God's own gracious self-revelation has been given so that God may be personally known. God's revelation then is supremely evangelistic; 'Like some piercing air-raid siren it sends us scurrying from life's preoccupations and warns us that no escape remains if we neglect the only sure sanctuary' (Henry 1999: volume 2, 17).

Henry's understanding of the doctrine of revelation forms the central basis for his prioritizing evangelism and his emphasis on redemption. God's redemptive purposes lie at the very heart of God's special revelation in Scripture and in Christ. This can be seen in that Scripture defines revelation using the Hebrew word galah and the Greek verb apokaluptō-both of which center on the idea of an unveiling of something hidden (Henry 1999: volume 2, 21). What is unveiled is God's own nature and purpose. The only manner in which this unveiling takes place is through the reality of Scripture, the imago Dei, and mediating logos (from John 1). Not only has God spoken a redemptive message, but through the imago Dei and the mediating logos, He sets humanity in a position to comprehend that revelation. Therefore, sinful persons stand inescapably accountable to God, thereby heightening the urgency of the church's evangelistic efforts, for one never knows when the offer of God's gracious self-revelation will come to an abrupt end (Henry 1999: volume 2, 30-34). The crucial idea here is that Christianity exists as revealed religion and God acts in the world to accomplish His redemptive purposes. Therefore, Henry finds cause for concern among liber- 
al and secular tendencies to downplay this motif and warns against confusing evangelism and social concern-or of reducing evangelism to merely attacking social or political evils. To do so is to commit the ultimate act of lovelessness, for it neglects humanity's greatest need, namely personal redemption and supernatural regeneration (Henry 1967: 36; cf. Henry 2003: 39; Henry 1964: 307).

Henry's critique of liberal and secular fallacies regarding the benevolence of God might also be applied to some holism perspectives, such as that of Scott J. Jones, who tend to equivocate evangelism and social concern and define them in such a way that it becomes difficult to know where one begins and the other ends (Jones 2003: 16, 60-61). According to Henry, since Christianity exists particularly as a verbally-revealed religion, proclamation uniquely defines the very essence of Christianity in a way nothing else does (Henry 1999: volume 3, 13-63). Because of this, it is slightly off base, then, to say that evangelism and social concern are 'two wings of the same bird' or 'two sides of the same coin'. Scripture never equates these two things in such an overtly parallel manner, even though Scripture upholds the necessity and importance of both.

As it relates to the issue of priority, one can easily trace through both the OT and NT an emphasis on God's otherwise hidden nature and purposes that are made known only because God has graciously revealed them. This emphasis is brought into focus by looking at God's divinely revealed names, which from YHWH to Jesus emphasize God's redemptive intents and progressively self-revelatory acts. The names of God especially underscore God's redemptive presence and initiative (Henry 1999: volume 2, 151-240). Furthermore, God's nature and purposes are verbally revealed through the prophets and apostles. This verbal revelation and its unique role in bringing forth true and accurate knowledge of God forms the basis of the church's evangelistic and redemptive mandate. Apart from this, God would remain obscured as general revelation only lends itself to condemnation and guilt, not to salvation (Henry 1999: volume 2, 283-290). Therefore, 'The content of church proclamation', Henry says, is

not just about anything and everything. The church's message to the world is not about the energy crisis, pollution, white or black power, détente, the Israeli-Arab conflict, ad infinitum. It is the very specific Word of God.' He adds, with equal force, 'nor is the Christian minister anything and everything-a fundraiser, marriage counselor, pulpit orator, public relations specialist... He is primarily the proclaimer of God's revealed Word (Henry 1999: volume 2, 22).

If we were to stop here, we might all readily agree that Henry was a prioritist in the purest sense. But Henry does not stop here, and it is very important that we consider what he has to say about social concern as well. As 
we do, we discover that Henry is something of an anomaly among prioritists. This is evident in that Henry calls the church to actively address social evils in ways that go beyond its evangelistic task, even though evangelism and revival remain the primary well-spring of social change (Henry 1980: 26).

\section{Henry's Argument for the Necessity of Social Concern}

Henry held that all moral obligations were rooted in God's own nature and that, therefore, religious devotion and moral obedience could never be divorced from one another. In fact, they are never separated from one another in Scripture. God not only rescues sinners from hell and judgment, but creates a new society, the church, that sets before the world the qualities of the Kingdom of God. Thus, Christian social concern is not about the creation of a new society, but about providing evidence that one has come already, at least in part, through the person and work of Christ (Henry 1979: 98). As Henry explains, 'The ascended Lord wants to extend his victory over sin and evil through us, the new society, and enjoins us to be light and salt to the world. We are to have an illuminating and a preserving role, one that includes the ministry of compassion, the benevolent ministry of the Church throughout history' (Henry 1979: 99). Within this regenerational approach, Christian compassion is neither a means to an end nor an add-on to biblical faith. It is fundamental to it and cannot be viewed as optional or as merely a means to evangelism. Henry explicitly warns against this by declaring, 'The church dare not be interested in social injustices merely as an occasion for evangelism. She has a standing responsibility to the province of social justice' (Henry 1980: 121). In this, Henry presents a direct challenge to Bosch's claim that integration and prioritism are mutually exclusive. More precisely, he defines his approach to social concern as a 'regenerational model', which he says achieves 'transformation through supernatural impulse in individual lives whereby the social scene is renewed through divine spiritual motivation' (Henry 1980: 16-17).

Henry believes that there are four common approaches to the issue of Christian social concern: revolution, reform, revaluation, and regeneration. Revolution can be defined as an approach that advocates all means necessary, even violence, to achieve its goals. Reform similarly relies on the power of government to compel social action from its citizens. Similarly, revaluation seeks to compel moral obligations by emphasizing the superiority of human creatures to the animal and material world. But only a regenerational model rests its success on spiritual power and on the gospel. As with evangelism, then, there exists a direct link between the doctrine of revelation and social concern. As Henry explains, 'The new birth restores man to fellowship with God, and lifts him not only to the vision of truth and good- 
ness but also qualifies him with a new nature and moral power to place his energies in the service of righteousness' (Henry 1980: 25).

We might be compelled to ask precisely how this differs from the fundamentalist paradigm that Henry challenged. The answer is that fundamentalism, for the most part, stopped short of encouraging an active social agenda based on the reality of reborn citizens within a society. In other words, fundamentalism rightly focused people on the centrality of the cross and the priority of evangelism, but failed to motivate them to fully appreciate the fullness of their spiritual rebirth. Henry called upon the church to recapture the moral power available through the Risen Christ in a way reflective of the apostolic age:

Christ founded neither a party of revolutionaries, or a movement of reformers, nor a remnant of revaluators. He 'called out a people'. The twice-born fellowship of his redeemed Church, in vital company with its Lord, alone mirrored the realities of the new social order. This new order was no mere distant dream, waiting for the proletariat to triumph, or the evolutionary process to reach its pinnacle, or truth to win its circuitous way through the world. In a promissory way, the new order had come already in Jesus Christ and in the regenerate fellowship of the church. The Lord ascended; he reigned over all. Hence the apostolic church would not yield to other rulers or to other social visions. It could not obey some earthly leader, covet some power other than the gospel, or reverence some man-made commission. The Christian church knew Jesus Christ. He furnished the spiritual resources for its moral confrontation with the world (Henry 1980: 28).

Henry argues that where social concern is absent, the power of evangelism is diminished. It is important to understand what Henry means here and what he does not mean. He does not mean that social concern is necessary in order for the gospel to be credible. The gospel is credible all on its own. Nor does he say, as some have, that social concern is the greatest way in which the gospel is demonstrated. The greatest demonstration of the gospel was in the person and work of Jesus and in the gospel's saving power. That said, Henry calls on the church to not just tell the world, but to also show the world what 'life made whole truly is' (Henry 1984: 21). Therefore, Henry issues a strong warning about the dangers of ignoring social concern saying, 'The temptation to stress evangelism only as 'the Christian answer' and to withdraw from social confrontation is dangerous and one that Protestant orthodoxy had best avoid' (1971: 43). For Henry, this is perhaps the most important lesson to be learned from fundamentalist withdrawal. As Moore has noted, this withdrawal 'isolated fundamentalism from the society it sought to evangelize' with disastrous consequences (2004: 84).

One of the very important issues that Henry raises in developing his theology of social concern is that of the Kingdom of God. Henry helpfully 
points out that the biblical concept of the Kingdom of God-which is a vital biblical theme-has sadly become a point of contention. He specifically laments fundamentalism's apprehensions about the Kingdom, noting that this apprehension is, first of all, reactionary and theology should never be reactionary.

In other words, evangelicals should never develop theological positions solely in response to the excess of others. The excess he refers to is of course the excess of the social gospel and theological liberalism which tended to interpret the Kingdom of God solely as participation in social good. This led many within fundamentalism to overly spiritualize the Kingdom in response. The problem with such a reactionary approach is that it is simply unbiblical since Scripture says a great deal about socio-ethical requirements for God's people and links those requirements to the reign of God. This is evident in numerous OT passages that link God's own reign to His demand for justice and righteousness and also in NT passages in which Jesus' followers are called to 'prayerful yearning and active working for the extension of God's Kingdom' (Luke 1:17; Matt 6:10; Henry 1999: volume 6, 431434).

Henry argues forcefully that the church is called to show forth the qualities of the Kingdom, and that there is an evangelistic component to this as well as a social component. The evangelistic component flows from the fact that when the church lives according to the ethical demands of the Kingdom of God, then in doing so it proleptically sets the world before the judgment seat of Christ by declaring the standards by which God will judge the world (Henry 2003: 37-88). Again, the regenerational emphasis emerges as the central feature.

George Marsden helpfully sums up exactly why Henry succeeds in advocating a Kingdom ethic for the people of God while so many others on both sides of the debate have struggled to find the right balance. Marsden writes:

Henry worked out more clearly than did most of his evangelical colleagues the puzzling question of how social and political efforts could be Kingdom work while the Kingdom could never be equated with social, political, or national programs. His solution was essentially a version of Augustine's two cities conception, which sees a distinction between the city of God and the city, or civilization, of earth. Kingdom principles can influence the earthly city, but can never be fully realized there in this age (Marsden 1987: 81).

\section{Toward a Regenerational Model}

In closely examining Henry's perspective, it becomes evident that he has related these two tasks of the church in a manner similar to that of $\mathrm{C}$. $\mathrm{H}$. Dodd, who distinguished didache from kerygma. Dodd pointed out that kerygma represents the church's unique message of salvation, namely the gos- 
pel, whereas didache refers to the church's teachings and Scripture's ethical demands. Similarly, Henry has said that kerygma especially relates to what it means to fulfill the Great Commission. But that is not all. The church sent into the world to share the good news of Christ is also called to live as citizens of two worlds and witness to the world of the abundant life Christ offers (Henry 1971: 62; Dodd 1964: 8-38; cited in Stott 2008: 67-68).

Both kerygma and didache are essential, but they are not essential in the same way. Kerygma (proclamation) is essential because it is the only means given in Scripture by which God's will and offer of salvation are known. Didache, the process of discipleship that includes moral formation and ethical demands, is crucial to spiritual growth. But without proclamation there can be no disciples. Therefore, holism advocates like Orlando Costas who wish to label any differentiation between the gospel and its effects as dichotomizing, must come to terms with the problematic reality that such a distinction is found in Scripture itself (cf. Costas 1992: 38). It is, therefore, important that we distinguish the gospel from the demands of the gospel and avoid equivocating the two if we are to be faithful to Scripture. When this is done, then we can advocate for both the priority of evangelism and for a robust Christian social concern.

The claim, such as that made by Bosch, that prioritism and integration are mutually exclusive is simply a false claim. As mentioned, I had previously believed this claim to be true and have said so in print. But Henry presents a potent challenge to this notion because he was clearly a prioritist, but also evidenced a clear passion for social concern. He saw them both as necessary and, thus, he helps us to see how a prioritist position can indeed hold these together. Certainly, we can point to advocates of a prioritist position who lacked interest in social action.

But this does not mean that there is, therefore, a necessary correlation. Plus, we can readily conceive of examples from everyday life that demonstrate the weakness of Bosch's claim. For example, I might say that I am going to go to the bank to make a deposit and then to the post office to mail some bills. I furthermore declare that the bank is my top priority because if I do not deposit my paycheck, then the bills cannot be paid.

Clearly, one has here a case of priority in which both things remain necessary. I still must deposit my check and I still must pay my bills. Yet one of these takes priority because the second thing depends on the first thing having taken place. It is the same with evangelism and social concern. The gospel must first be preached before converts can be discipled and, indeed, the content of Christian discipleship remains mired in obscurity apart from the proclamational foundations of the apostles and prophets, which is divine revelation. Thus, the logical priority of evangelism does not render compas- 
sion as optional. It simply affirms the ultimate place of Scripture and the unequivocal role given to proclamation in the life of the church.

\section{Macro Priority, not Micro Priority}

Henry's priority position refers to a macro priority not a micro priority, though he never uses these precise terms. This notion has since been echoed by a number of scholars who have recently written on the subject (Litfin 2012: conclusion; Flemming 2013: 264-269; Wright 2006: 317-318). Henry argued that Scripture deals almost exclusively in macro priority, focusing especially on guiding principles rather than specific programs (1980, 129). In advocating this idea, Henry criticized both the Jesus movement of the 1960 s and 1970s along with the group of socially-active Christians associated with Ron Sider's Chicago Declaration because of their individualism and anti-institutionalism.

In other words, these seemed more concerned with promoting specific social programs than with fostering local churches that functioned as salt and light in the community. Henry was concerned that though both groups importantly tackled social issues, they did so generally from a stance of antipathy toward the church. This very problem also lay at the center of almost all imbalances regarding Christian social concern, including those of theological liberalism and fundamentalism. In all of these, there was a tendency to ignore the NT understanding of church as a visible institution. The church formed by Christ was to display certain characteristics in the world as the body of Christ, and these were to define its very nature (macro priority). As Henry explains:

From one biblical perspective, the Jesus movement, the Chicago Declaration of young evangelicals, independent fundamentalist churches, and even the socalled evangelical establishment, no less than the ecumenical movement which promoted structural church unity, all suffer a basic lack, namely, public identity as a 'people', a conspicuously unified body of regenerate believers. Evangelical Christians in their fragmented condition no less than ecumenical Christians in their structural affiliation seem to lack the realization that Christ's church is to be a 'new community' (1999: volume 1, 133).

For Henry, a focus on broad Scriptural principles is necessary to maintain the institutional church's primary focus on making disciples. Where biblical principles have not been kept central, the result has been confusion over the church's role in society and the neglect of personal social ethics, which is fundamentally a discipleship issue (Henry 1980: 121-125). Regarding the move from principles to practice, Henry argues that the Christian believer must evaluate each situation with concrete biblical teaching. He writes, 'To avoid being dismissed as indifferent to the culture in which it exists... the 
Christian movement will need to evaluate the live contemporary options, and to indicate whether they conform with sound biblical principles' (Henry 1980: 126; cf. Litfin 2012, conclusion).

In other words, though such a priority must govern the church's selfunderstanding (macro priority), proclamation will not always take priority in everyday life (micro priority). There will be times when it is necessary to feed the hungry or rescue victims of trafficking before sharing with them the good news. The priority of evangelism, though, simply means that ultimately we want every person to know Jesus, the Word made flesh, and accept his offer of salvation. Therefore, all that the church does should either begin with or find its way back to that central feature. Since God's will and offer of salvation are verbally given, and because there is no other name under heaven by which men can be saved (Acts 4:12), there must be, as Christopher Wright says, an 'ultimacy' to the evangelistic task that is uniquely definitive for the mission of the Church (Wright 2006: 319). This is, I think, precisely what Henry meant when he talked about the priority of proclamation.

Henry's instructive theology of evangelism and social concern highlights the need to recover a manner of talking about the church's missionary mandate in a way that emphasizes macro priorities. Contemporary discussions have largely become bogged down, though, and the terms prioritism and holism appear to have too much baggage to be of much use owing to various misconceptions.

For example, when prioritists hear the word holism, many inherently attribute to it the neglect of evangelism. Conversely, when holists hear the word prioritism, this implies Bosch's paradigm and the relegation of social concern to optional status. These concepts, false as they are, have become ingrained in the evangelical conscience. Yet we gain nothing by continuing to talk about prioritism and holism if we cannot even agree what those terms mean. Perhaps then, it is time to adopt better terminology that captures the ultimate nature of evangelism as a macro priority, along with the necessary nature of social concern.

I think Henry's terminology-a regenerational model-has great promise in this regard. The need for individual regeneration is the driving force behind evangelism and is the central focus of the doctrine of revelation. Similarly, from the regenerate life flows a Kingdom ethic in which the Church models for the world life made whole. In this life, Christ's followers become salt and light (Matthew 5:13-16), a city on a hill that cannot be hidden (Matthew 5:14), radiant with practical expressions of love and compassion in a world of increasing darkness and moral ambiguity. 


\section{Bibliography}

Brand CO (1999) Is Carl Henry a Modernist? Rationalism and Foundationalism in Post-War Evangelical Theology. Trinity Journal 20(1): 3-21.

Bosch D (1991) Transforming Mission. Maryknoll, NY: Orbis.

Cerillo Jr. A, Dempster MW (1991) Carl F. H. Henry's Early Apologetic for an Evangelical Social Ethic, 1942-1956. Journal of the Evangelical Theological Society 34(3): 365-379.

Costas O (1992) Christ Outside the Gate: Mission Beyond Christendom. Maryknoll, NY: Orbis.

Dodd CH (1964) Apostolic Preaching and Its Development. New York, NY: Hodder \& Stoughton.

Flemming DE (2013) Recovering the Full Mission of God: A Biblical Perspective on Being, Doing, and Telling. Downers Grove, IL: IVP Academic.

France RT (1989) Matthew: Evangelist and Teacher. Grand Rapids, MI: Zondervan.

Henry CFH (1967) Evangelicals at the Brink of Crisis. Waco, TX: Word Books. (1971) Plea for Evangelical Demonstration. Grand Rapids, MI: Baker Book House.

(1972) The Tension Between Evangelism and Christian Concern for Social Justice. Fides et Historia 4(*):3-10.

(1979) Evangelicals and the Social Scene: God's Plan for Salvation and Justice. In Hancock RL (ed) The Ministry of Development. Pasadena, CA: William Carey Library, pp. 96-103.

- (1980) Aspects of Christian Social Ethics. Grand Rapids, MI: Eerdmans. (1984) The Christian Mindset in a Secular Society: Promoting Evangelical Renewal छ National Righteousness. Portland, OR: Multnomah Press.

(1986) Christian Countermoves in a Decadent Culture. Portland, OR: Multnomah Press.

- (1988) Twilight of a Great Civilization. Westchester, IL: Crossway.

(1990) Toward a Recovery of Christian Belief: The Rutherford Lectures. Wheaton, IL: Crossway Books.

— (1999) God, Revelation, and Authority, 6 volumes. Wheaton, IL: Crossway.

(1947, 2003) The Uneasy Conscience of Modern Fundamentalism. Grand Rapids, MI: Eerdmans.

Hesselgrave DJ (2005) Paradigms in Conflict: 10 Key Questions in Christian Missions Today. Grand Rapids, MI: Kregel Publications.

Ireland J (2015) Evangelism and Social Concern in the Theology of Carl F. H. Henry. Eugene, OR: Pickwick.

Jones SJ (2003) The Evangelistic Love of God and Neighbor. Nashville, TN: Abingdon.

Keener C (1997) Matthew. Downers Grove, IL: IVP Academic. 
Kirk JA (1983) The Good News of the Coming Kingdom. Downers Grove, IL: Intervarsity Press.

Litfin D (2012) Word vs. Deed: Resetting the Scales to a Biblical Balance. Wheaton, IL: Crossway.

Little C (2005) What Makes Mission Christian? Mission Studies 22(2): 207226.

(2013) Polemic Missiology in the 21st Century. Amazon Digital Services.

Marsden G (1987) Reforming Fundamentalism: Fuller Seminary and the New Evangelicalism. Grand Rapids, MI: Eerdmans.

Miles D (1986) Evangelism and Social Involvement. Nashville, TN: Broadman Press.

Moore RD (2004) The Kingdom of Christ. Wheaton, IL: Crossway.

Nash RH (1982) The Word of God and the Mind of Man. Phillipsburg, NJ: P\&R.

Neuhaus RJ (1989) A Prophetic Jeremiad. Christianity Today (April 7): 30.

Olson R (2007) Reformed and Always Reforming: A Postconservative Approach to Theological Method. Grand Rapids, MI: Baker Academic.

Sider R (1993) Good News and Good Works. Grand Rapids, MI: Baker.

Stott J (ed) (1996) Making Christ Known: Historic Mission Documents from the Lausanne Movement, 1974-1989. Grand Rapids, MI: Eerdmans.

(2008) Christian Mission in the Modern World. Downers Grove, IL: Intervarsity Press.

Thornbury GA (2013) Recovering Classic Evangelicalism: Applying the Wisdom and Vision of Carl F. H. Henry. Wheaton, IL: Crossway.

Tizon A (2008) Transformation After Lausanne. Eugene, OR: Wipf \& Stock.

Trueman C (2000) Admiring the Sistine Chapel: Reflections on Carl F. H. Henry's God, Revelation, and Authority. Themelios 25(2): 48-58.

Vanhoozer K (2005) The Drama of Doctrine. Louisville, KY: Westminster John Knox.

Wright C (2006) The Mission of God: Unlocking the Bible's Grand Narrative. Downers Grove: IVP Academic.

[This article first appeared in Sheuermann RC, Smither EL, eds (2016) Controversies in Missions. Pasadena, CA: William Carey. Reprinted with permission.] 